\title{
COVID-19 in Children: A Single Center Experience from Istanbul, Turkey
}

\section{Çocuklarda COVID-19: İstanbul, Türkiye'den Tek Merkez Deneyimi}

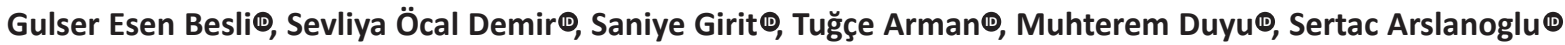

Department of Pediatrics, Istanbul Medeniyet University Faculty of Medicine, Goztepe Research and Training Hospital, Istanbul, Turkey.

Received: 15.02.2021 / Accepted: 01.03.2021 / Published Online: 31.03.2021

Cite as: Besli GE, Öcal Demir S, Girit S, Arman T, Duyu M, Arslanoglu S. Covid-19 in children: a single center experience from Istanbul, Turkey. Med J Bakirkoy 2021;17(1):64-71.

\section{ABSTRACT}

Objective: We aimed to evaluate the demographic, epidemiological, and clinical characteristics of children with coronavirus disease-2019 (COVID-19), and to determine variations of the clinical presentation of the disease by age.

Method: A total of 104 confirmed COVID-19 patients aged between 0-18 years were retrospectively analyzed. The study period was between March 15, 2020 and July 1, 2020. A confirmed COVID-19 was defined as a child who has positive real-time reverse transcription-polymerase chain reaction (rRT-PCR). The patients were analyzed in terms of demographic, epidemiological, clinical, laboratory and imaging features, and clinical outcomes.

Results: The median age (inter-quartile range) of the patients was 11.8 (8.4) years, and 53 (51\%) were male. Ninety-eight (94\%) of the patients had an epidemiological risk factor. The most frequent symptoms were cough (62\%), fever (42\%), and fatigue (33\%). Seven patients (7\%) were asymptomatic, 84 (81\%) were mild, 9 (9\%) were moderate, and 4 (4\%) were in severe or critical condition. Ninety-eight (94\%) of the patients underwent a chest $x$-ray, and $12 \%$ had pneumonia. The patients younger than 5 years were more likely to have fever ( $p=0.019)$, rhinorrhea $(p=0.041)$, and diarrhea $(p=0.035)$. Muscle/join pain (26\%), loss of smell/taste (20\%), and headache (19\%) were striking extrapulmonary symptoms in older patients. Only $8 \%$ of the patients were hospitalized, and $4 \%$ were admitted to the intensive care unit. No death occurred.

Conclusion: The most of the pediatric COVID-19 cases have mild symptoms without pneumonia. They may not present with fever or cough which are considered characteristic symptoms of the disease and the frequency of signs and symptoms may vary by age. Children younger than 5 years old are more likely to have fever, rhinorrhea, and diarrhea. School-age children and adolescents may present with extrapulmonary symptoms such as muscle/join pain, smell/taste loss, and headache.

Keywords: COVID-19, SARS-CoV-2, children, clinical characteristics

Öz

Amaç: Bu çalışmada, COVID-19 tanısı alan çocukların demografik, epidemiyolojik ve klinik özelliklerini değerlendirmeyi ve klinik bulguların yaşa göre değişkenlik gösterip göstermediğini belirlemeyi amaçladık.

Yöntem: 0-18 yaşları arasında toplam 104 kesin COVID-19 hastası geriye dönük olarak analiz edildi. Çalışma dönemi 15 Mart 2020-1 Temmuz 2020 idi. Kesin COVID-19 vakası, gerçek-zamanlı reverse transkripsiyon polimeraz zincir reaksiyonu (rRT-PCR) testinin ağır akut solunum sendromu-koronavirüs-2 (SARS-CoV-2) enfeksiyonu için pozitif saptanması olarak tanımlandı. Hastalar demografik özellikleri, epidemiyolojik risk faktörleri, klinik bulguları, laboratuvar ve görüntüleme sonuçları ve klinik sonuçları açısından analiz edildi.

Bulgular: Hastaların medyan yaşı (çeyrekler arası genişlik) 11,8 (8,4) yıl olup, 53’ü (\%51) erkekti. Hastaların 98'inde (\%94) epidemiyolojik risk faktörü vardı. En sık görülen semptomlar öksürük (\%62), ateş (\%42) ve yorgunluk (\%33) idi. Hastaların 7'si (\%7) asemptomatik, 84'ü (\%81) hafif, 9'u (\%9) orta ve 4'ü (\%4) ağır/kritik olarak sınıflandıııldı. Hastaların 98'ine (\%94) akciğer grafisi çekildi ve \%12'sinde pnömoni saptandı. Beş yaşından küçük hastalarda ateş $(p=0.019)$, burun akıntısı $(p=0.041)$ ve ishal $(p=0.035)$ sıklğı daha fazlaydı. Kas/eklem ağrısı (\%26), koku/tat kaybı (\%20) ve baş ağrııı (\%19) ise 5 yaşından büyük hastalarda en sık görülen solunum dışı semptomlar arasındaydı. Hastaların \%8'i hastaneye, \%4'ü çocuk yoğun bakım ünitesine yatıııldı. Ölüm saptanmadı.

Sonuç: Pediyatrik COVID-19 vakalarının çoğunda pnömoni olmaksızın hafif hastalık bulguları gelişir. Hastalar karakteristik belirtiler olarak kabul edilen ateş ve öksürük ile başvurmayabilir, belirti ve bulgular yaşa göre değişkenlik gösterebilir. Beş yaşından küçük çocuklarda ateş, burun akıntısı ve ishal görülme sıklığı daha fazladır. Okul çağı çocukları ve ergenler kas/eklem ağrısı, koku/tat kaybı, ve baş ağrısı gibi solunum dışı belirtilerle başvurabilir.

Anahtar kelimeler: COVID-19, SARS-CoV-2, çocuk, klinik özellikler

Corresponding Author:

esenbesli@yahoo.com
G.E. Besli 0000-0001-6837-5384

S. Öcal Demir 0000-0002-7175-303X

S. Girit 0000-0001-7556-6568
T. Arman 0000-0002-5896-6719

M. Duyu 0000-0001-7892-2927

S. Arslanoglu 0000-0002-1636-9991

(C) Telif hakkı Sağlık Bilimleri Üniversitesi Bakırköy Dr. Sadi Konuk Eğitim ve Araştırma Hastanesi'ne aittir. Logos Tıp Yayıncılık tarafindan yayınlanmaktadır. Bu dergide yayınlanan bütün makaleler Creative Commons Atff-GayriTicari 4.0 Uluslararası Lisansı ile lisanslanmıştı.

(c) Copyright Health Sciences University Bakırköy Sadi Konuk Training and Research Hospital. This journal published by Logos Medical Publishing.

Licenced by Creative Commons Attribution-NonCommercial 4.0 International (CC BY) 


\section{INTRODUCTION}

In mid-December 2019, a new respiratory tract infection appeared in Wuhan, Hubei province, China. The virus isolated from the lower respiratory tract of the patients showed that this was a new type of coronavirus ${ }^{(1)}$. The etiologic agent was called as severe acute respiratory syndrome coronavirus-2 (SARS-CoV-2), and the disease was named as coronavirus disease-2019 (COVID-19) by World Health Organization. It caused an epidemic throughout China, followed by a rapidly spreading in other countries throughout the world. On March 11, 2020, WHO declared that COVID-19 caused a pandemic (2). In Turkey, the first COVID-19 case was detected on March 11, 2020 and Istanbul province has become an epicenter with the greatest number of patients in the country ${ }^{(3)}$.

Current evidence show that children of all ages are susceptible to be infected with SARS-CoV-2 but are less likely to be symptomatic or develop severe symptoms compared to the adults ${ }^{(4-9)}$. However, lifethreatening severe manifestations such as multisystem inflammatory syndrome in children (MIS-C), severe pneumonia, acute respiratory distress syndrome (ARDS), myocarditis, shock, coagulation dysfunction, and death can rarely occur ${ }^{(8-11)}$. As experience and data on COVID-19 have been increasing worldwide, new signs and symptoms are being identified other than fever and respiratory findings. In this study, we aimed to evaluate the demographic, epidemiological, and clinical characteristics of the children admitted to our hospital and diagnosed with COVID-19, and to determine variations of the clinical presentation of the disease by age.

\section{MATERIALS AND METHODS}

\section{Design, Setting, and Definitions}

This retrospective observational cohort study was conducted in a tertiary care hospital in Istanbul, Turkey, which became one of the pandemic hospitals. The confirmed COVID-19 patients admitted and treated in the pediatric emergency department (PED), inpatient ward, or pediatric intensive care unit (PICU) were included. The study period was between March 15, 2020 and July 1, 2020. The study was approved by the Institutional Ethics Committee of the hospital.

A suspected COVID-19 case was defined in accordance with our national guideline which has been prepared and intermittently revised by the "COVID-19 Scientific Board" as new information has emerged about the disease. A confirmed COVID-19 case was defined as a child with positive real-time reverse transcription-polymerase chain reaction (rRT-PCR) test result for SARS-CoV-2 infection ${ }^{(12) .}$ During the study period, indications for rRT-PCR

Table 1. Indications of rRT-PCR Sampling for SARS-CoV-2*

\begin{tabular}{|l|l|}
\hline Criteria & \multicolumn{1}{c|}{ Description } \\
\hline Epidemiological features (I) & $\begin{array}{l}\text { Having a household member hospitalized with a diagnosis of respiratory tract infection within the last 14 } \\
\text { days } \\
\text { Having a household member diagnosed with COVID-19 } \\
\text { Having a household member with fever and cough or suffering from respiratory distress either fever or } \\
\text { not } \\
\text { Having a contact history with an individual diagnosed with COVID-19 }\end{array}$ \\
\hline Signs and symptoms (II) & $\begin{array}{l}\text { Presence of a fever history or a measured body temperature of } \geq 38.0^{\circ} \mathrm{C} \\
\text { Presence of abnormal lung auscultation findings } \\
\text { Presence of tachypnea } \\
\text { Presence of new onset cough } \\
\text { Having an oxygen saturation of 92\% or lower in room air } \\
\text { Presence of diarrhea }\end{array}$ \\
\hline rRT-PCR testing is indicated & $\begin{array}{l}\text { The presence of at least one of each of I and II } \\
\text { The presence of at least two of II (for each item, failure to indicate any association with another reason) } \\
\text { Presence of two or more people with COVID-19 diagnosis in the same household } \\
\text { Infants under } 9 \text { months who have a mother diagnosed with COVID-19 } \\
\text { Newborns whose mother diagnosed with COVID-19 during pregnancy }\end{array}$ \\
\hline
\end{tabular}

*Adopted from The Republic of Turkey Ministry of Health Directorate General of Public Health COVID-19 Guide (12).

COVID-19: Coronavirus Disease-2019, rRT-PCR: Real-time reverse transcription-polymerase chain Reaction, SARS-CoV-2: Severe Acute Respiratory Syndrome Coronavirus-2 
Table 2. Disease severity*

\begin{tabular}{|c|c|}
\hline Criteria & Description \\
\hline Asymptomatic & $\begin{array}{l}\text { No signs or symptoms } \\
\text { AND normal chest X-ray, if performed }\end{array}$ \\
\hline Mild & $\begin{array}{l}\text { Symptoms of upper respiratory tract infection and/or gastrointestinal involvement } \\
\text { AND no hypoxemia and respiratory distress } \\
\text { AND no physicial examination findings consistent with pneumonia } \\
\text { AND normal chest X-ray, if performed }\end{array}$ \\
\hline Moderate & $\begin{array}{l}\text { No hypoxemia and respiratory distress } \\
\text { AND pneumonia on chest X-ray with or without positive clinical findings } \\
\text { OR sick appereance (such as poor feeding, dehydration) }\end{array}$ \\
\hline Severe & $\begin{array}{l}\text { Respiratory distress } \\
\text { OR hypoxemia (oxygen saturation }<92 \% \text { ) } \\
\text { OR need for respiratory support }\end{array}$ \\
\hline Critical & $\begin{array}{l}\text { Respiratory failure } \\
\text { OR need for intensive care admission } \\
\text { OR shock, } \\
\text { OR encephalopathy, myocardial injury or heart failure, coagulation disorders, acute kidney injury }\end{array}$ \\
\hline
\end{tabular}

*Adapted from Dong $\mathrm{Y}$ et al, and Chen ZM et al ${ }^{(4,14)}$.

sampling were shown in Table 1. The definitions of anemia, leukocytosis, leukopenia, lymphopenia, and thrombocytopenia were made based on lower and upper limit values of these parameters varying according to age ${ }^{(13)}$. Severity of COVID-19 was categorized adapting previous published classifications ${ }^{(4,14)}$ (Table 2).

\section{Study Population and Data Collection}

A total of 104 patients aged between 0-18 years with confirmed COVID-19 diagnosis during the study period were retrospectively analyzed. The patients older than 18 years or having missing medical data were excluded. The data of the patients was extracted from the medical database of the hospital and PED charts.

\section{Procedures}

A combined nasal and oropharyngeal swab samples were collected for rRT-PCR assay and were transported to the laboratories that had been authorized by the General Directorate of Public Health ${ }^{(12)}$. The test was repeated within 48 hours for all patients admitted to the hospital and whose first test results were negative.

Laboratory analysis was performed in patients with moderate, severe, and critical disease, in patients with underlying comorbidities, and in all patients less than one year old. Chest $\mathrm{x}$-ray was performed in all symptomatic patients. Computed tomography (CT) was performed only in patients with severe and critical disease condition and when the respiratory system findings could not be explained with chest $x$-ray. The patients who were discharged from the hospital were quarantined with their families for two weeks and followed up daily by their family doctors.

\section{Statistical Analysis}

The statistical analyzes and graphics were performed using The Statistical Package for Social Sciences (SPSS) version 22.0 (IBM Corp., Armonk, NY). The patients were analyzed in terms of demographic variables, epidemiological risk factors, initial clinical findings, baseline laboratory and imaging results, and clinical outcomes. Shapiro Wilk test was used to determine whether continuous variables were normally distributed, and the homogeneity of variances was evaluated by Levene test. Continuous variables were expressed as means and standard deviations or as median and inter-quartile ranges (IQR), if not normally distributed. Categorical data were expressed as counts and percentages. When comparing numerical variables, Student's t-test was used for normally distributed data and Mann-Whitney $U$ test was used for non-normally distributed data. The chi-square test or Fisher's exact probability test was used to compare qualitative data. The results were considered significant at a $p$ level $<0.05$.

\section{RESULTS}

The median age (IQR) of the patients was 11.8 (8.4) years, and $53(51 \%)$ were male. Ninety-eight (94\%) 
Table 3. Baseline characteristics of the patients

\begin{tabular}{|c|c|c|c|c|}
\hline Variable & $\begin{array}{l}\text { Overall } \\
\mathrm{n}=104\end{array}$ & $\begin{array}{c}>5 \text { years } \\
\mathrm{n}=85\end{array}$ & $\begin{array}{c}\leq 5 \text { years } \\
n=19\end{array}$ & $\mathbf{P}$ \\
\hline \multicolumn{5}{|l|}{ Gender $^{+}$} \\
\hline Male & $53(51.0)$ & $44(51.8)$ & $9(47.4)$ & 0.803 \\
\hline Comorbidities $^{+}$ & $11(10.6)$ & $11(12.9)$ & $0(0.0)$ & 0.209 \\
\hline Epidemiological history ${ }^{+}$ & $98(94.2)$ & $82(96.5)$ & $16(84.2)$ & 0.073 \\
\hline \multicolumn{5}{|l|}{ Systemic symptoms } \\
\hline Highest temperature, $\left({ }^{\circ} \mathrm{C}\right)^{\ddagger}$ & $37.0(1.5)$ & $37.0(1.5)$ & $38.0(1.8)$ & $0.034 *$ \\
\hline Fever, $\left(\geq 38^{\circ} \mathrm{C}\right)^{+}$ & $44(42.3)$ & $31(36.5)$ & $13(68.4)$ & $0.019 *$ \\
\hline Fatigue $^{+}$ & $34(32.7)$ & $27(31.8)$ & $7(36.8)$ & 0.788 \\
\hline Muscle or join pain ${ }^{+, \S}$ & - & $22(25.9)$ & - & N/A \\
\hline Loss of appetite $^{+}$ & $31(29.8)$ & $22(25.9)$ & $9(47.4)$ & 0.094 \\
\hline Headache $^{+, \S}$ & - & $16(18.8)$ & - & N/A \\
\hline \multicolumn{5}{|l|}{ Respiratory symptoms $^{+}$} \\
\hline Cough & $64(61.5)$ & $51(60.0)$ & $13(68.4)$ & 0.606 \\
\hline Shortness of breath & $8(7.7)$ & $7(8.2)$ & $1(5.3)$ & $>0.999$ \\
\hline \multicolumn{5}{|c|}{ Otorhinolaryngological symptoms $^{+}$} \\
\hline Sore throat ${ }^{5}$ & - & $16(18.8)$ & - & N/A \\
\hline Rhinorrhea & $5(4.8)$ & $2(2.4)$ & $3(15.8)$ & $0.041 *$ \\
\hline Loss of smell or taste ${ }^{\S}$ & - & $17(20.0)$ & - & $\mathrm{N} / \mathrm{A}$ \\
\hline \multicolumn{5}{|l|}{ Gastro-intestinal symptoms $^{+}$} \\
\hline Nausea/vomiting & $8(7.7)$ & $7(8.2)$ & $1(5.3)$ & $>0.999$ \\
\hline Diarrhea & $8(7.7)$ & $4(4.7)$ & $4(21.1)$ & $0.035 *$ \\
\hline Abdominal pain & $5(4.8)$ & $5(5.9)$ & $0(0.0)$ & 0.582 \\
\hline \multicolumn{5}{|l|}{ Vital parameters $^{+}$} \\
\hline Hypoxemia & $2(1.9)$ & $2(2.4)$ & $0(0.0)$ & $>0.999$ \\
\hline Tachypnea & $5(4.8)$ & $4(4.7)$ & $1(5.3)$ & $>0.999$ \\
\hline Tachycardia & $28(26.9)$ & $26(30.6)$ & $2(10.5)$ & 0.091 \\
\hline Hypotension & $0(0.0)$ & $0(0.0)$ & $0(0.0)$ & - \\
\hline \multicolumn{5}{|l|}{ Lung auscultation $^{+}$} \\
\hline Crackles & $6(5.8)$ & $4(4.7)$ & $2(10.5)$ & 0.301 \\
\hline Rhonchi & $2(1.9)$ & $2(2.4)$ & $0(0.0)$ & $>0.999$ \\
\hline Decreased sounds & $1(1.0)$ & $1(1.2)$ & $0(0.0)$ & $>0.999$ \\
\hline Chest X-ray & $\mathrm{n}=98$ & $\mathrm{n}=79$ & $\mathrm{n}=19$ & \\
\hline Suggestive of pneumonia & $12(12.2)$ & $10(12.7)$ & $2(10.5)$ & $>0.999$ \\
\hline \multicolumn{5}{|l|}{ Disease severity $^{+}$} \\
\hline Asymptomatic & $7(6.7)$ & $6(7.1)$ & $1(5.3)$ & \multirow{4}{*}{0.253} \\
\hline Mild & $84(80.8)$ & $70(82.3)$ & $14(73.6)$ & \\
\hline Moderate & $9(8.6)$ & $7(8.2)$ & $2(10.5)$ & \\
\hline Severe to critical & $4(3.8)$ & $3(3.5)$ & $1(5.3)$ & \\
\hline \multicolumn{5}{|l|}{ Respiratory support $^{+}$} \\
\hline Face mask oxygen & $2(0.9)$ & $1(1.2)$ & $0(0.0)$ & \multirow{3}{*}{0.458} \\
\hline NIV/HFNCO & $2(1.9)$ & $1(1.2)$ & $1(5.3)$ & \\
\hline IMV & $0(0.0)$ & $0(0.0)$ & $0(0.0)$ & \\
\hline \multicolumn{5}{|l|}{ Clinical decision $^{+}$} \\
\hline Discharged from PED & $92(88.5)$ & 79 (92.9) & $13(68.4)$ & \multirow{3}{*}{$0.005 *$} \\
\hline Hospitalization & $8(7.7)$ & $3(3.5)$ & $5(26.3)$ & \\
\hline ICU admission & $4(3.8)$ & $3(3.5)$ & $1(5.3)$ & \\
\hline Mortality $^{+}$ & $0(0.0)$ & $0(0.0)$ & $0(0.0)$ & - \\
\hline
\end{tabular}

$*_{p}<0.05$ is statistically significant.

'Values are presented as number (\%).

${ }^{\ddagger}$ Values are presented as median (interquartile range).

${ }^{5}$ Values are applicable in children $>5$ years.

COVID-19: Coronavirus disease-2019, HFNCO: High flow nasal cannula oxygen, ICU: Intensive care unit, IMV: Invasive mechanical ventilation, NA: not available, NIV: Noninvasive mechanical ventilation, PED: Pediatric emergency department 
of the patients had an epidemiological risk factor. The most frequent symptoms were cough (62\%), fever $(42 \%)$, and fatigue (33\%). The frequency of various signs and symptoms of lower respiratory tract infection (shortness of breath, tachypnea, hypoxemia, lung auscultation findings) was $2-8 \%$. Gastrointestinal symptoms were observed in $5-8 \%$ of the patients (Table 3 ).

Out of the 104 patients, 7 (7\%) were younger than 1 year of age, 12 (11\%) were between $1-5$ years of age and $85(82 \%)$ were older than 5 years of age. It was found that patients younger than 5 years old were more likely to have fever $\geq 38^{\circ} \mathrm{C}(p=0.019)$, rhinorrhea $(p=0.041)$, and diarrhea $(p=0.035)$, and their maximum body temperature was higher $(p=0.034)$ than the patients older than 5 years. On the other hand, muscle or join pain (26\%), loss of smell or taste (20\%), and headache (19\%) were among the most common extra-pulmonary symptoms in patients older than 5 years (Table 3).

Regarding the disease severity of positive cases; 7 (7\%) were asymptomatic, 84 (81\%) were mild, 9 (9\%) were moderate, and $4(4 \%)$ were in severe or critical condition. Ninety-eight (94\%) of the patients underwent a chest $x$-ray, and only $12 \%$ had pathological findings consistent with pneumonia. Only $5(5 \%)$ of the patients underwent a chest CT. There was no significant difference between the age groups in terms of the presence of pneumonia and disease severity. However, the frequency of hospitalization was higher in the patients younger than 5 years $(26 \%$ vs $4 \%, p=0.005)$. When the course of the disease was evaluated, a total of $88 \%$ of the patients were discharged from the PED, $8 \%$ of the patients were hospitalized at the inpatient COVID-19 ward, and 4\% were admitted to the PICU. Only $3 \%$ of the patients received respiratory support and none was intubated. No death occurred (Table 3). No patient was diagnosed with MIS-C during the study period. Baseline laboratory findings of the patients were shown in Table 4.

\section{DISCUSSION}

Data from China showed that most of the children (75-90\%) with COVID-19 had a documented family contact history ${ }^{(5,15)}$. In European studies, $50-60 \%$ of the children with COVID-19 had a family contact history which was lower than Chinese findings, probably due to the late lockdown ${ }^{(16,17)}$. In Turkey, schools were closed immediately after the detection of the first case in the country, and home isolation for children had been implemented starting from the beginning of the outbreak. In different pediatric studies reported from Turkey, exposure has been reported in $90-99 \%{ }^{(18,19)}$. Similarly, in our case series, the source of infection in almost all children with COVID-19 was a household member or an immediate family mem-

Table 4. Baseline laboratory findings of the patients

\begin{tabular}{|l|c|c|c|c|}
\hline Variable & $\begin{array}{c}\text { Overall } \\
\mathrm{n}=24\end{array}$ & $\begin{array}{c}>\mathbf{5} \text { years } \\
\mathrm{n}=16\end{array}$ & $\begin{array}{c}\mathbf{5} \text { years } \\
\mathrm{n}=8\end{array}$ & $\boldsymbol{P}$ \\
\hline Anemia & $4(16.7 \%)$ & $3(18.8 \%)$ & $1(12.5 \%)$ & $>0.999$ \\
\hline Thrombocytopenia & $3(12.5 \%)$ & $3(18.8 \%)$ & $0(0.0 \%)$ & 0.526 \\
\hline Leukocytosis & $2(8.3 \%)$ & $1(6.3 \%)$ & $1(12.5 \%)$ & $>0.999$ \\
\hline Leukopenia & $3(12.5 \%)$ & $3(18.8 \%)$ & $0(0.0 \%)$ & 0.526 \\
\hline Neutropenia & $2(8.3 \%)$ & $2(12.5 \%)$ & $0(0.0 \%)$ & 0.536 \\
\hline Lymphopenia & $5(20.8 \%)$ & $4(25.0 \%)$ & $1(12.5 \%)$ & 0.631 \\
\hline CRP elevation & $8(33.3 \%)$ & $5(31.3 \%)$ & $3(37.5 \%)$ & $>0.999$ \\
\hline PCT elevation & $0(0.0 \%)$ & $0(0.0 \%)$ & $0(0.0 \%)$ & $\mathrm{N} / \mathrm{A}$ \\
\hline Troponin elevation & $2(8.3 \%)$ & $2(12.5 \%)$ & $1(12.5 \%)$ & $>0.999$ \\
\hline CK elevation & $1(4.2 \%)$ & $1(6.3 \%)$ & $0(0.0 \%)$ & 0.532 \\
\hline LDH elevation & $5(20.8 \%)$ & $3(18.8 \%)$ & $2(25.0 \%)$ & 0.624 \\
\hline Hepatic dysfunction & $2(8.3 \%)$ & $1(6.3 \%)$ & $1(12.5 \%)$ & $>0.999$ \\
\hline Renal dysfunction & $2(8.3 \%)$ & $2(12.5 \%)$ & $0(0.0 \%)$ & 0.536 \\
\hline
\end{tabular}

Values are presented as number (\%). CK: Creatine kinase, CRP: C-reactive protein; LDH: Lactate dehydrogenase, NA: Not available, PCT: Procalcitonin 
ber. We have found no gender difference in line with the literature ${ }^{(4,8,9,17) \text {. }}$

The clinical presentations of COVID-19 in children are diverse. Although the frequency of the typical symptoms of acute respiratory infections including fever and cough was less reported in pediatric COVID-19 patients than adults, fever and cough are still the most common signs and symptoms of the disease occurring in almost half of the pediatric patients. Fatigue was also common reported (7-9,14$17,20,21$ ). Being in line with the studies, our results demonstrated that the most common symptoms in children with COVID-19 were cough, fever, and fatigue determined in almost two-third, a half, and one-third of the patients, respectively.

The current evidence shows that the majority of the children with COVID-19 have mild disease and are less likely to progress severe acute respiratory distress syndrome, respiratory failure, septic shock, metabolic acidosis and coagulopathy which can develop more common in adults ${ }^{(4-9)}$. The frequency of respiratory distress was $5-13 \%$ in different pediatric COVID-19 studies $(4,7,8,20,21)$. The large pediatric series from China showed that only $0.6 \%$ of the patients progressed to ARDS or multiple organ dysfunction (4). In two pediatric studies from Turkey, dyspnea or tachypnea were observed less than $5 \%$ of the patients ${ }^{(18,19)}$. Similarly, the majority of our patients (81\%) had mild disease. The frequency of shortness of breath and tachypnea was less than $10 \%$, and only one patient (1\%) progressed to ARDS.

Children with COVID-19 can present with extra-pulmonary symptoms. Among them, gastrointestinal symptoms (10-25\%), fatigue or muscle pain (10$25 \%)$, and headache (10-30\%) were mainly reported $(5-9,15-17,20,21)$. In our study, fatigue was the most common extra-pulmonary symptom which was observed in one-third of the patients. Gastrointestinal symptoms were less frequent (5-8\%). Muscle or join pain and headache were evaluated only in children older than 5 years old, and were determined in $26 \%$ and $19 \%$ of the patients, respectively.

A sudden-onset smell or taste loss is another extrapulmonary symptom in COVID-19 which was first described in adult patients ${ }^{(22-24)}$. In contrast to other acute viral smell impairment, COVID-19-associated smell loss is usually not with concomitant nasal obstruction ${ }^{(22,23)}$. It was argued that loss of smell and taste is a potential clinical predictor of COVID-19 in adults $(23,25,26)$. However, there is limited information on smell and/or taste disorders in pediatric COVID-19, and were not mentioned in most of the large pediatric case series ${ }^{(7-9,17,20,27)}$. Qiu et al ${ }^{(28)}$ firstly reported that approximately one third of the infected children older than 6 years presented with smell and/or taste loss, and a quarter of these patients had no additional symptoms. In our study, $20 \%$ of the patients older than 5 years (varying from 8.8-17.9 years) reported loss of smell or taste, and concomitant nasal obstruction was found only in one case.

We found some differences concerning the frequency of symptoms with regard to age. The patients younger than 5 years presented more frequently with fever, rhinorrhea, and diarrhea. On the other hand, muscle or join pain, loss of smell or taste, and headache were striking extra-pulmonary symptoms in children older than 5 years.

It is known that children with COVID-19 are less likely to be hospitalized when compared to adult patients ${ }^{(8)}$. However, a wide range of hospitalization (5.7-62\%) and PICU admission rates (0.6-9.7\%) was reported from different countries ${ }^{(7,8,15,17,29)}$. It was argued that this difference may rise from the use of different criteria for admission to the hospital or $\mathrm{PICU}$, the number of children with underlying conditions, or different host responses to the infection ${ }^{(16,29)}$. In one of the largest series in children with COVID-19, the proportions of severe and critical cases were higher in cases under 5 years old, especially in infants ${ }^{(4)}$. In USA, children younger than one year old had the highest percentage of hospitalization ${ }^{(7)}$. In another study, being younger than one month was found to be associated with ICU admission ${ }^{(17)}$. In our series, only $8 \%$ of the patients were hospitalized and $4 \%$ were admitted to the PICU. Although the rate of hospitalization was significantly higher in cases less than 5 years ( $26 \%$ versus $4 \%$ ), it was more likely due to the physicians' concern to observe the course of the disease closely in this group, rather than the severity of the disease.

In laboratory, lymphocytopenia were common in adult patients with COVID-19 ${ }^{(30)}$. In contrast to adult 
data, complete blood counts are usually normal in children with COVID-19 although lymphopenia, leucopenia, and leukocytosis were reported in some case series $(8,9,14,20)$. The frequency of $\mathrm{C}$-reactive protein (CRP) or procalcitonin elevation has been reported between $10-30 \%{ }^{(9-20)}$. In our study, the most common abnormality in the leukocyte counts was lymphopenia $(21 \%)$. About one-third of the patients had elevated CRP levels. A previous study reported that the children older than 5 years old had decreased lymphocytes, elevated procalcitonin, and decreased creatine kinase levels compared with the younger patients ${ }^{(31)}$. Our laboratory test results did not demonstrate any difference between the age groups.

Chinese studies mainly involving mild to moderate pediatric COVID-19 cases reported that half to twothirds of the cases who underwent lung tomography had pneumonia ${ }^{(5,15,31)}$. In a multinational European study, approximately one third of the cases underwent a chest $x$-ray, and almost half had findings consistent with pneumonia ${ }^{(17)}$. In our study, we evaluated all symptomatic patients with chest $\mathrm{x}$-ray, and $12 \%$ revealed pneumonia. However, it is known that chest X-ray may fail to identify typical lesions ${ }^{(20)}$. Therefore, the cases of subclinical pneumonia without clinical and $x$-ray findings may have not been identified as we rarely used chest computed tomography to avoid radiation exposure.

The study has some limitations. First, this was a single-center, retrospective study. Second, a blood sampling which is an invasive procedure in children was not obtained from any of the patients who were asymptomatic or who had a mild clinical condition unless there was any of the underlying comorbidities or risk factors, or a clinical requirement observed by the physician. These limitations led to a small sample size.

\section{CONCLUSION}

Our results demonstrated that the most of the pediatric COVID-19 cases had mild symptoms without pneumonia. They may not present with fever or cough which are considered characteristic symptoms of the disease, and the frequency of signs and symptoms may vary by age. While children younger than 5 years old are more likely to have fever, rhinorrhea, and diarrhea, school-age children and adolescents may present with extra-pulmonary symptoms such as muscle or join pain, smell or taste loss, and headache.

Ethics Committee Approval: Istanbul Medeniyet University Faculty of Medicine Ethics Committee approval was received (01/07/2020; 2020/0434).

Conflict of Interest: No conflict of interest was declared by the authors.

Funding: No funding was used for this study.

\section{REFERENCES}

1. Hui DS, Azhar El, Madani TA, et al. The continuing 2019-nCoV epidemic threat of novel coronaviruses to global health - The latest 2019 novel coronavirus outbreak in Wuhan, China. Int J Infect Dis. 2020;91:264-6. doi: 10.1016/j.ijid.2020.01.009.

2. World Health Organization. WHO Director-General's opening remarks at the media briefing on COVID-19 - 11 March 2020. Available from: https://www.who.int/director-general/speeches/detail/who-director-general-s-opening-remarks-at-themedia-briefing-on-covid-19---11-march-2020

3. Republic of Turkey Ministry of Health. COVID-19 Situation Report Turkey, October 19-25, 2020. Available from: https://dosyamerkez.saglik.gov.tr/Eklenti/39230,covid-19-weekly-situationreport---43pdf.pdf?0\&_tag1=D3D202441F1F5165A33D16981E6 544EF7FCOA32F

4. Dong Y, Mo X, Hu Y, et al. Epidemiology of COVID-19 among children in China. Pediatrics. 2020;145(6):e20200702. doi: 10.1542/peds.2020-0702.

5. Lu X, Zhang L, Du H, et al. SARS-CoV-2 infection in children. N Engl J Med. 2020;382:1663-5. doi: 10.1056/NEJMc2005073.

6. Wu Z, McGoogan JM. Characteristics of and important lessons from the coronavirus disease 2019 (COVID-19) outbreak in China: Summary of a report of 72314 patients from the Chinese Center for Disease Control and Prevention. JAMA. 2020;323(13):1239-42. doi:10.1001/jama.2020.2648.

7. CDC COVID-19 Response Team. Coronavirus disease 2019 in children - United States, February 12-April 2, 2020. MMWR Morb Mortal Wkly Rep. 2020;69:422-6. doi: 10.15585/mmwr.mm6914e4.

8. Hoang A, Chorath K, Moreira A, et al. COVID-19 in 7780 pediatric patients: Asystematic review. EClinicalMedicine. 2020;24:100433. doi: 10.1016/j.eclinm.2020.100433.

9. Mustafa NM, Selim AL. Characterization of COVID-19 pandemic in paediatric age group: a systematic review and meta-analysis. J Clin Virol. 2020;128:104395. doi: 10.1016/j.jcv.2020.104395.

10. Bertoncelli D, Guidarini M, Della GA, et al. COVID19: potential cardiovascular issues in pediatric patients. Acta Biomed. 2020;91:177-83. doi: 10.23750/abm.v91i2.9655.

11. Bautista-Rodriguez C, Sanchez-de-Toledo J, Clark BC, et al. Multisystem inflammatory syndrome in children: an international survey. Pediatrics. 2021;147(2):e2020024554. doi: 10.1542/peds.2020-024554.

12. T. C. Sağlık Bakanlığı, Halk Sağlığı Genel Müdürlüğü. COVID-19 (SARS-CoV-2 Enfeksiyou) Genel Bilgiler, Epidemiyoloji ve Tanı 
(Bilimsel Danışma Kurulu Çalıșması). December 7, 2020. Available from: https://covid19.saglik.gov.tr/TR-66337/genel-bilgilerepidemiyoloji-ve-tani.html

13. Lanzkowsky P, ed. Hematological reference values. In: Manual of pediatric hematology and oncology. 5th ed. Burlington: Elsevier; 2011. p. 969-95. https://doi.org/10.1016/B978-0-12-375154-6.00043-4

14. Chen ZM, Fu JF, Shu $Q$, et al. Diagnosis and treatment recommendations for pediatric respiratory infection caused by the 2019 novel coronavirus. World J Pediatr. 2020;16:240-6. doi: 10.1007/s12519-020-00345-5.

15. Chang TH, Wu JL, Chang LY. Clinical characteristics and diagnostic challenges of pediatric COVID-19: A systematic review and metaanalysis. J Formos Med Assoc. 2020;119:982-9. doi: 10.1016/j.jfma.2020.04.007.

16. Parri $\mathrm{N}$, Lenge $\mathrm{M}$, Buonsenso D. Children with Covid-19 in pediatric emergency departments in Italy. N Engl J Med. 2020;383:187-90. doi: 10.1056/NEJMc2007617.

17. Götzinger F, Santiago-García B, Noguera-Julián A, et al. COVID-19 in children and adolescents in Europe: a multinational, multicenter cohort study. Lancet Child Adolesc Health. 2020;4:653-61. doi: 10.1016/S2352-4642(20)30177-2.

18. Korkmaz MF, Türe E, Dorum BA, Kılıç ZB. The Epidemiological and Clinical Characteristics of 81 Children with COVID-19 in a Pandemic Hospital in Turkey: An Observational Cohort Study. J Korean Med Sci. 2020;35:e236. doi: 10.3346/jkms.2020.35.e236.

19. Cura Yayla BC, Ozsurekci Y, Aykac K, et al. Characteristics and management of children with COVID-19 in Turkey. Balkan Med J. 2020;37:341-7. doi: 10.4274/balkanmedj.galenos.2020.2020.7.52.

20. Liguoro I, Pilotto C, Bonanni M, et al. SARS-COV-2 infection in children and newborns: a systematic review. Eur J Pediatr. 2020;179:1029-46. doi: 10.1007/s00431-020-03684-7.

21. Parri N, Magistà AM, Marchetti F, et al. Characteristic of COVID19 infection in pediatric patients: early findings from two Italian Pediatric Research Networks. Eur J Pediatr. 2020;179:1315-23. doi: 10.1007/s00431-020-03683-8.

22. Haehner A, Draf J, Dräger S, de With $K$, Hummel T. Predictive value of sudden olfactory loss in the diagnosis of COVID-19. ORL J Otorhinolaryngol Relat Spec. 2020;82:175-80. doi: 10.1159/000509143.
23. Salmon Ceron D, Bartier S, Hautefort C, et al. Self-reported loss of smell without nasal obstruction to identify COVID-19. The multicenter Coranosmia cohort study. J Infec. 2020;81:614-20. doi: 10.1016/j.jinf.2020.07.005.

24. Giacomelli A, Pezzati L, Conti F, et al. Self-reported olfactory and taste disorders in patients with severe acute respiratory coronavirus 2 infection: a cross-sectional study. Clin Infect Dis. 2020;71:889-90. doi: $10.1093 / \mathrm{cid} / \mathrm{ciaa330.}$

25. Menni C, Valdes AM, Freidin MB, et al. Real-time tracking of selfreported symptoms to predict potential COVID-19. Nat Med. 2020;26:1037-40. doi: 10.1038/s41591-020-0916-2.

26. Yan CH, Faraji F, Prajapati DP, Boone CE, DeConde AS. Association of chemosensory dysfunction and COVID-19 in patients presenting with influenza-like symptoms. Int Forum Allergy Rhinol. 2020;10:806-13. doi: 10.1002/alr.22579.

27. Erdede O, Sarı E, Uygur Külcü N, Uyur Yalçın E, Sezer Yamanel RG. An overview of smell and taste problems in paediatric COVID-19 patients. Acta Paediatr. 2020;109:2184-6. doi: 10.1111/apa.15515.

28. Qiu C, Cui C, Hautefort C, et al. Olfactory and gustatory dysfunction as an early identifier of COVID-19 in adults and children: an international multicenter study. Otolaryngol Head Neck Surg. 2020;163:714-21. doi: 10.1177/0194599820934376.

29. Tagarro A, Epalza C, Santos M, et al. Screening and severity of coronavirus disease 2019 (COVID-19) in children in Madrid, Spain. JAMA Pediatr. 2020;e201346. doi: 10.1001/jamapediatrics.2020.1346.

30. Guan W, Ni Z, Yu H, et al. Clinical characteristics of coronavirus disease 2019 in China. N Engl J Med. 2020;382:1708-20. doi: 10.1056/NEJMoa2002032.

31. Qiu H, Wu J, Hong L, Luo Y, Song Q, Chen D. Clinical and epidemiological features of 36 children with coronavirus disease 2019 (COVID-19) in Zhejiang, China: an observational cohort study. Lancet Infect Dis. 2020;20:689-96. doi: 10.1016/S1473-3099(20)30198-5. 